\title{
INDICATORS FOR SOCIAL STRUCTURE IN THE GÁTA- -WIESELBURG CEMETERY OF HEGYESHALOM, HUNGARY
}

\author{
E S Z T E R M E L IS
}

\begin{abstract}
In 1965 and 1966 inhumation burials dated to the transition between the Hungarian Early and Middle Bronze Age (Central European EBA; $2100-1600$ cal BC), were discovered at the site of Hegyeshalom-Újlakótelep. This cemetery with its 58 graves represents the largest burial ground of the Gáta-Wieselburg culture on the territory of Hungary. Beside the intense recent disturbances, at least $36 \%$ of the burials were deliberately reopened sometime in the past. The method of the so-called Combined Social Index Calculation was applied to assess the 'value' of individual burials in the context of the cemetery as a whole. Even with the high disturbance rate present at the burial ground, indicators of social inequality were still noticeable: the two outstanding female graves, the high status burials and the ones representing the lowest social ranks can be distinguished clearly from the middle class burials based on the statistical analysis of the grave structure and grave goods.
\end{abstract}

Keywords: North-Western Hungary, Hegyeshalom, Early Bronze Age, inhumation burial, social index, socio-archaeological analysis.

\section{INTRODUCTION}

In recent years, the social structures indicative of the Bronze Age in Central Europe have been described mainly as chiefdom-type societies or have been reconstructed as a network of looser, tribal communities going through a process of gradual centralisation (Earle/Kristiansen 2010). Others, however, emphasise heterarchical relationships that could have existed between Bronze Age social groups (Kienlin 2015). In this regard, the power of a certain individual can derive from four possible sources: economy, military, political and social relations - or the combination of these (Dani et al. $2016,219,220)$. In terms of the origins of chiefdoms, two main theoretical models can be distinguished. The first is the theory of the 'great man' which is thought to have emerged primarily out of ideological and sociopolitical (family based) relationships. The second is the model of the 'big man', in which case the power of the leader rests chiefly on his/her economic position. Undoubtedly, neither of these models exists on their own in real-life circumstances and the process of power centralisation and its transfer can be lengthy and often disrupted. The detailed examination of burials can shed more light potentially on some of these social processes and transformations (Sosna 2009, 4-8).

Since people do not 'bury themselves', the selection of objects that accompany the deceased, and the method of burial is reflective of the individual and his/her role in the community or in other words, the person's social identity (Bösel 2008, fig. 3; RebaySalisbury et al. 2018, 79). Therefore, during the ex- amination of cemeteries, observations detailing the types and shapes of materials used for grave goods are particularly important, along with descriptions of the grave's structure and size (Bösel 2008). Based on their spectacular grave structures (such as burial mounds) and grave goods (like gold objects, overdisplay of weaponry) the society of the Early Bronze Age Únětice culture in central Germany is assumed to have been strictly hierarchical, whose leaders buried under mounds (princely graves) could have wielded power over several regions (Meller 2017). However, since the complex nature of social hierarchies and their effects on a number of spheres of daily life, in the future, settlements and their structures should also be examined alongside cemeteries (Dani et al. 2016). As a first step towards this aim, the present paper focuses on the indicators of social differences in burials through the examples of the inhumation cemetery of Hegyeshalom associated with the Gáta-Wieselburg culture (2100-1600 cal BC).

\section{EXAMINATION OF SOCIAL HIERARCHIES IN THE MIDDLE BRONZE AGE CEMETERIES OF WESTERN}

\section{HUNGARY}

Until recently, social inequalities in the Middle Bronze Age cemeteries from Western Hungary have been investigated through the comparison of grave goods in terms of their number, material and types (Dani et al. 2016; Kiss 2012, 247-255). Complex statistical analysis has only been carried out on 

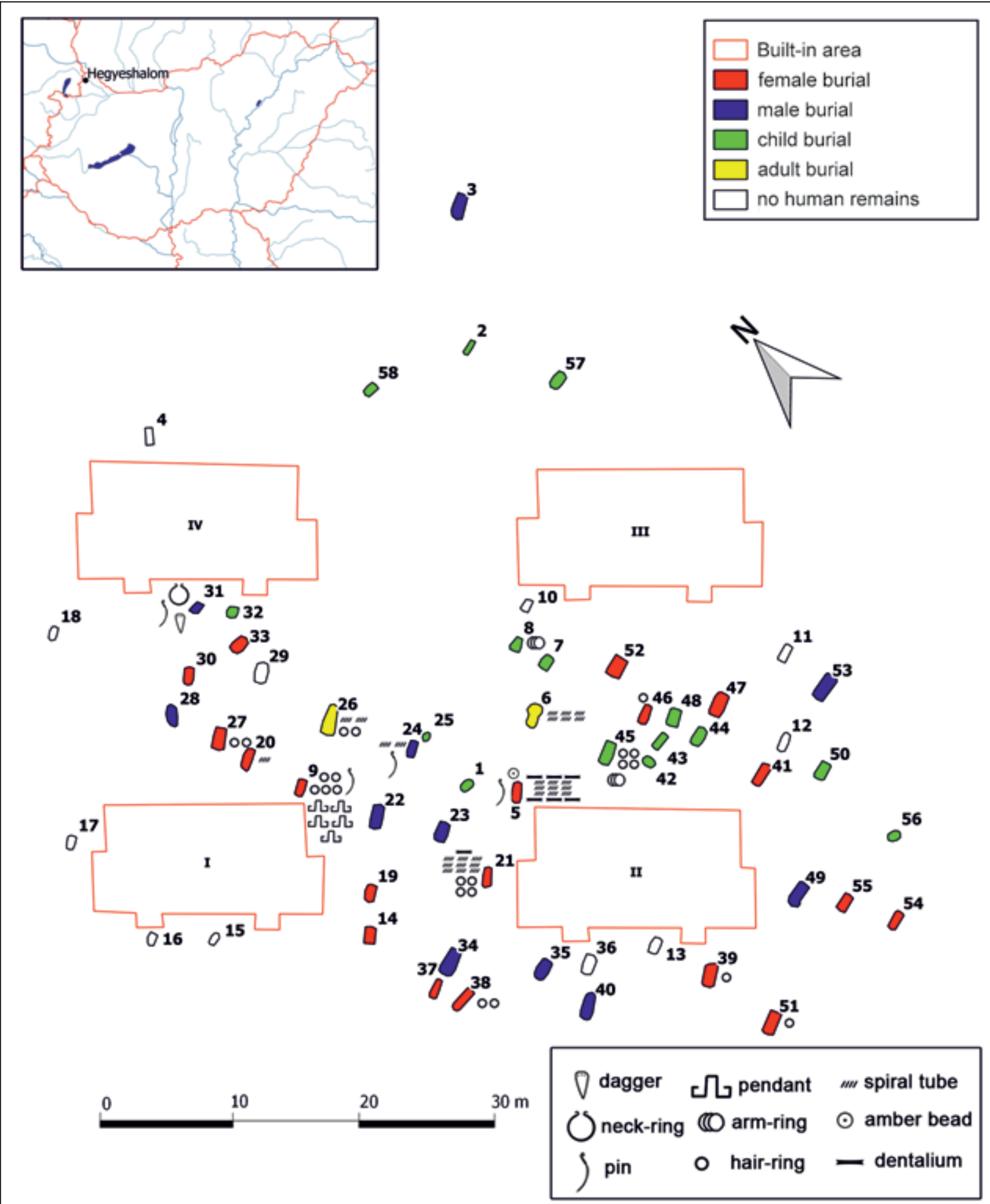

Fig. 1. The site plan of Hegyeshalom-Újlakótelep with the determined age and gender groups and symbols of bronze, dentalium, amber grave goods (caution: the number of spiral beads represented here is only proportional). Digitised site plan based on the documentation by R. Pusztai. 
Table 1. Overview of graves and grave goods (their association index in brackets) from the cemetery at Hegyeshalom-Újlakótelep (age and sex determination after Zoffmann 1999, with a few exceptions marked by their monograms in brackets: TH - Tamás Hajdu, anthropologist; KK - Kitti Köhler, anthropologist; RP - Rezső Pusztai, archaeologist, excavator).

\begin{tabular}{|c|c|c|c|c|c|c|c|c|c|c|c|c|c|c|}
\hline $\begin{array}{l}\dot{0} \\
\mathbf{z} \\
\mathbf{0} \\
\text { J0 }\end{array}$ & 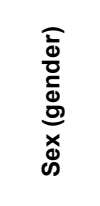 & 量 & 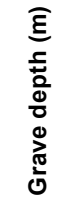 & 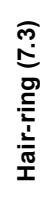 & 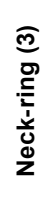 & 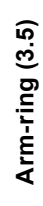 & $\begin{array}{l}\underset{\frac{0}{c}}{c} \\
\frac{c}{a}\end{array}$ & 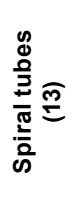 & 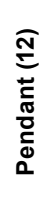 & 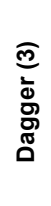 & 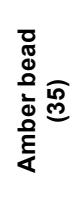 & 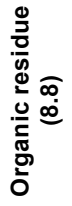 & 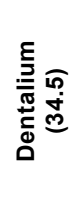 & $\begin{array}{l}\widehat{m} \\
\stackrel{+}{+} \\
\bar{\Phi} \\
\stackrel{D}{0} \\
\stackrel{\Delta}{>}\end{array}$ \\
\hline 001 & - & Juv. & 0.75 & - & - & - & - & - & - & - & - & - & - & 3 \\
\hline 002 & - & child (RP) & 0.95 & - & - & - & - & - & - & - & - & - & - & 0 \\
\hline 003 & male & Ad.-mat. & 0.95 & - & - & - & - & - & - & - & - & - & - & 4 \\
\hline 004 & - & - & 1.30 & - & - & - & - & - & - & - & - & - & - & 0 \\
\hline 005 & female & Ad. & 1.10 & - & - & - & 1 & 26 & - & - & 1 & 1 & 6 & 1 \\
\hline 006 & - & Ad.-sen. & 1.40 & - & - & - & - & 8 & - & - & - & - & - & 0 \\
\hline 007 & - & Inf. I-II & 0.90 & - & - & - & - & - & - & - & - & - & - & 5 \\
\hline 008 & - & $0-1$ & 1.05 & - & - & 1 & - & - & - & - & - & - & - & 1 \\
\hline 009 & female & Ad.-mat. & 0.90 & 5 & - & - & 1 & - & 5 & - & - & - & - & 2 \\
\hline 010 & - & - & - & - & - & - & - & - & - & - & - & - & - & 1 \\
\hline 011 & - & - & - & - & - & - & - & - & - & - & - & - & - & - \\
\hline 012 & - & - & - & - & - & - & - & - & - & - & - & - & - & - \\
\hline 013 & - & - & - & - & - & - & - & - & - & - & - & - & - & - \\
\hline 014 & female & Ad.-mat. & 1.00 & - & - & - & - & - & - & - & - & - & - & 0 \\
\hline 015 & - & - & - & - & - & - & - & - & - & - & - & - & - & - \\
\hline 016 & - & - & - & - & - & - & - & - & - & - & - & - & - & - \\
\hline 017 & - & - & - & - & - & - & - & - & - & - & - & - & - & - \\
\hline 018 & - & - & - & - & - & - & - & - & - & - & - & - & - & - \\
\hline 019 & female & Mat. & 0.90 & - & - & - & - & - & - & - & - & - & - & 4 \\
\hline 020 & female & Ad.-sen. & 0.75 & - & - & - & - & 1 & - & - & - & - & - & 2 \\
\hline 021 & female & Ad. & - & 4 & - & - & - & 25 & - & - & - & - & 1 & 5 \\
\hline 022 & male & Mat. & 0.95 & - & - & - & - & - & - & - & - & - & - & 1 \\
\hline 023 & male & Mat. & 0.80 & - & - & - & - & - & - & - & - & - & - & 4 \\
\hline 024 & male & Mat. & 0.60 & - & - & - & 1 & 2 & - & - & - & - & - & 0 \\
\hline 025 & - & child (RP) & 0.50 & - & - & - & - & - & - & - & - & - & - & 1 \\
\hline 026 & - & Ad.-sen. & 1.90 & 2 & - & - & - & 2 & - & - & - & - & - & 2 \\
\hline 027 & female & Ad.-sen. & 1.50 & 2 & - & - & - & - & - & - & - & 1 & - & 0 \\
\hline 028 & male & Ad.-mat. & 0.90 & - & - & - & - & - & - & - & - & - & - & 2 \\
\hline 029 & - & - & 1.00 & - & - & - & - & - & - & - & - & - & - & 0 \\
\hline 030 & female & Ad. & 0.75 & - & - & - & - & - & - & - & - & - & - & 0 \\
\hline 031 & male & Mat. & 1.10 & - & 1 & - & 1 & - & - & 1 & - & - & - & 1 \\
\hline 032 & - & $7-8$ & 0.80 & - & - & - & - & - & - & - & - & - & - & 0 \\
\hline 033 & female & Ad.-sen. & 0.70 & - & - & - & - & - & - & - & - & - & - & 4 \\
\hline 034 & male & Ad.-sen. & 0.70 & - & - & - & - & - & - & - & - & - & - & 7 \\
\hline 035 & male & Ad.-mat. & 1.25 & - & - & - & - & - & - & - & - & 1 & - & 1 \\
\hline 036 & - & - & 1.15 & - & - & - & - & - & - & - & - & - & - & 2 \\
\hline 037 & female & Mat.-sen. & - & - & - & - & - & - & - & - & - & - & - & 0 \\
\hline 038 & female & Mat. & 0.70 & 2 & - & - & - & - & - & - & - & - & - & 0 \\
\hline 039 & female & Juv. (TH) & 1.15 & 1 & - & - & - & - & - & - & - & 1 & - & 3 \\
\hline 040 & male & Mat. & 1.10 & - & - & - & - & - & - & - & - & - & - & 2 \\
\hline 041 & female & $14-40(\mathrm{TH})$ & 0.85 & - & - & - & - & - & - & - & - & 1 & - & 2 \\
\hline 042 & - & 4-8 (TH) & 0.55 & - & - & - & - & - & - & - & - & - & - & 0 \\
\hline $043 \mathrm{~A}$ & - & Inf. I-II (TH) & 0.50 & - & - & - & - & - & - & - & - & - & - & 0 \\
\hline
\end{tabular}


Table 1. Continued.

\begin{tabular}{|c|c|c|c|c|c|c|c|c|c|c|c|c|c|c|}
\hline $\begin{array}{l}\dot{0} \\
\mathbf{2} \\
\stackrel{0}{\pi} \\
0 \\
0\end{array}$ & 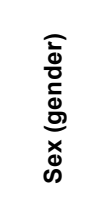 & $\stackrel{8}{\&}$ & 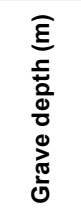 & 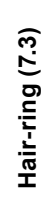 & 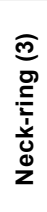 & 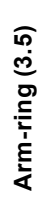 & $\begin{array}{l}\stackrel{\widehat{m}}{a} \\
\frac{a}{a}\end{array}$ & 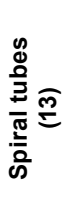 & 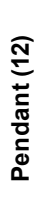 & 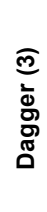 & 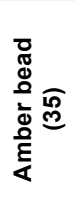 & 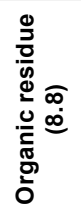 & 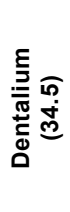 & 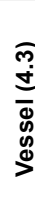 \\
\hline 043B & - & \pm 4 & 0.75 & - & - & - & - & - & - & - & - & - & - & 0 \\
\hline 044 & - & $9(\mathrm{TH})$ & 0.80 & - & - & - & - & - & - & - & - & - & - & 0 \\
\hline 045 & - & $11-12$ & 1.30 & 4 & - & 1 & - & - & - & - & - & - & - & 2 \\
\hline 046 & female & Mat. & 0.65 & 1 & - & - & - & - & - & - & - & - & - & 2 \\
\hline 047 & female & Ad.-sen. & 1.10 & - & - & - & - & - & - & - & - & - & - & 8 \\
\hline 048 & - & child (RP) & 0.85 & - & - & - & - & - & - & - & - & - & - & 0 \\
\hline 049 & male & Ad.-sen. & 1.20 & 1 & - & - & - & 1 & - & - & - & - & - & 5 \\
\hline 050 & - & child (RP) & 0.85 & - & - & - & - & - & - & - & - & - & - & 2 \\
\hline 051 & female & 18-22(TH) & 0.85 & 1 & - & - & - & - & - & - & - & - & - & 0 \\
\hline 052 & female & Ad.-mat. & 0.85 & - & - & - & - & - & - & - & - & - & - & 5 \\
\hline 053 & male & Mat. & 1.30 & - & - & - & - & - & - & - & - & - & - & 2 \\
\hline 054 & female & Ad. & 1.10 & - & - & - & - & - & - & - & - & - & - & 1 \\
\hline 055 & female & Ad.-mat. & 0.25 & - & - & - & - & - & - & - & - & - & - & 2 \\
\hline 056 & - & $\begin{array}{l}5-10(\mathrm{TH}) \\
+ \text { cremated } \\
\text { bones of an } \\
8-30-\text { year- } \\
\text {-old individu- } \\
\quad \text { al (KK) }\end{array}$ & 0.7 & - & - & - & - & - & - & - & - & - & - & 1 \\
\hline 057 & - & $4-5$ & 1.30 & - & - & - & - & - & - & - & - & - & - & 2 \\
\hline 058 & - & child (RP) & 1 & - & - & - & - & - & - & - & - & - & - & 1 \\
\hline sum & $\begin{array}{c}11 \\
\text { male, } \\
19 \\
\text { fema- } \\
\text { le, } 18 \\
\text { unde- } \\
\text { termi- } \\
\text { nable } \\
\text { sex }\end{array}$ & $\begin{array}{l}16 \text { children, } \\
32 \text { adults }\end{array}$ & $\begin{array}{c}\text { ave- } \\
\text { rage: } \\
0.94 \\
\text { m }\end{array}$ & 23 & 1 & 2 & 4 & 65 & 5 & 1 & 1 & 5 & 7 & 93 \\
\hline
\end{tabular}

the Biatorbágy cemetery of the contemporaneous Vatya culture, where about a hundred burials were examined. Here, in order to calculate the value of grave goods, the so-called Z-transformation, that combines both qualitative and quantitative methods, was applied (Bösel 2008; Mali 2014).

In terms of the Gáta-Wieselburg culture, so far there have only been two small inhumation cemeteries published in detail recently (Zsennye: Nagy 2013; Nagycenk: Gömöri/Melis/Kiss 2018). Based on the mortuary material of both burial grounds (23 graves from Zsennye and 27 from Nagycenk), it was possible to outline a similar fabric of social hierarchies as described at the Únětice culture (Meller 2017). Although the social stratum generally associated with the so-called princely graves cannot be identified with certainty in the cemeteries of the Gáta-Wieselburg culture, the lone male burial unearthed at Balatonakali ascribed to the Kisapostag culture, containing a number of solid cast weapons, large solid gold hair ring and a grave structure including stone slabs indicates that similar, high-status individuals could have existed in Western Hungary as well (Kiss 2020).

In the Gáta-Wieselburg cemeteries of Zsennye and Nagycenk, male burials accompanied by gold hair rings represent the highest level of the social hierarchy. Furthermore, in the cemetery of Nagycenk, burials with weapons and other special grave goods (e. g. diadems, neck rings, amber beads) associated with high social status can be distinguished from other burials furnished with smaller pieces of bronze artefacts. In both cemeteries there was a clear connection between individuals of high social status and the structure of their graves: gold hair rings and solid weapons were found in larger than average burial pits or coffins (Gömöri/Melis/ Kiss 2018, fig. 31; 32; 43; Nagy 2013, pl. 38; 39). Both at Nagycenk and Zsennye pottery was the leading artefact type among burials with grave goods. 


\section{THE CEMETERY OF HEGYESHALOM}

In 1965 and 1966 inhumation burials dated to the transition between the Hungarian Early and Middle Bronze Age (Central European EBA; 2100-1600 cal BC; Fischl et al. 2015, fig. 1a-b; Krenn-Leeb 2011), were discovered by Rezső Pusztai at the site of Hegyeshalom-Újlakótelep (HNM Archives XXIII 312/1966; HNM Archives V 91/1967). The burials were unearthed during the laying of water pipes following the construction of a building com- plex, thus it was not possible to carry out further extensive excavations (Fig. 1). The areas between the buildings were investigated which resulted in the discovery of 49 burials and the location of further nine disturbed burials. Although several Gáta-Wieselburg cemeteries in Eastern Austria contained hundreds of burials (Aspöck 2015, 34, fig. 3; Krenn-Leeb 2011), from the territory of Hungary, the partially excavated cemetery of Hegyeshalom with its 58 burials represents the largest Gáta-Wieselburg burial ground so far.

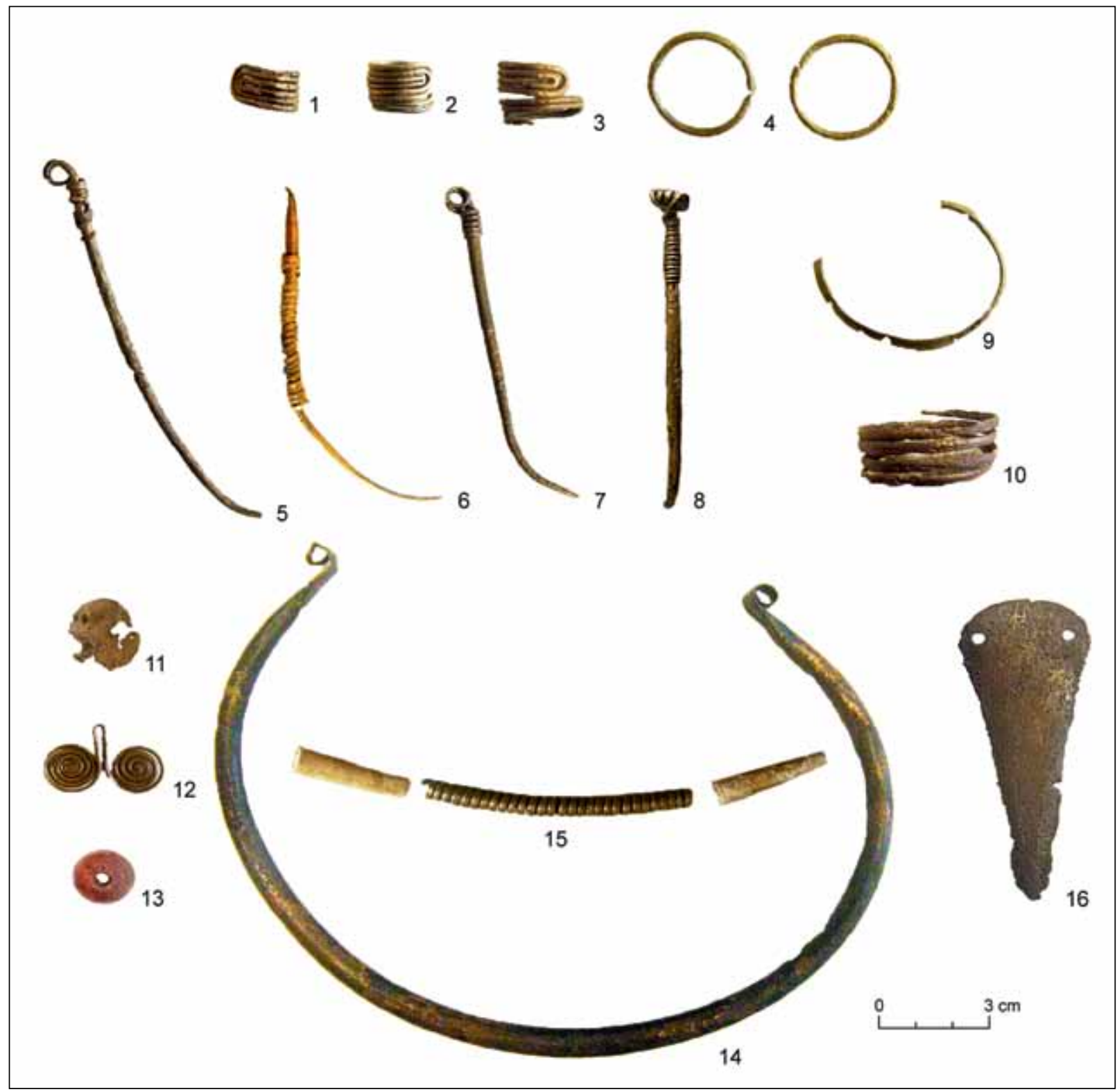

Fig. 2. Hegyeshalom-Újlakótelep. A selection of the leading types of bronze, dentalium and amber grave goods: 1-3 - bronze Noppenrings (No. 26, 45, 51); 4 - bronze hair- or ear-rings (No. 38); 5-8 - bronze pins (No. 31, 9, 24, 5); 9, 10 - bronze spiral arm-rings (No. 45, 8); 11, 12 - bronze pendants (No. 9); 13 - amber bead (No. 5); 14 - bronze neck-ring (No. 31); 15 - bronze tubular spiral bead and beads of dentalium shells (No. 5); 16 - bronze dagger (No. 31). 
The physical anthropological examination of the poorly preserved human bone assemblage from Hegyeshalom was carried out by Zsuzsanna K. Zoffmann, who identified the remains of 43 individuals (11 males, 19 females, 8 children and 5 adults; Zoffmann 1999). Based on the entries of the excavation diary, five further graves (No. 2, 25, 48, 50 and 58) can be assumed to be burials of children. Burial No. 56 contained cremated skeletal material examined by Kitti Köhler. More recently another examination targeting traces of patina on the human remains came to a slightly different conclusion, identifying a larger number of children's burials (altogether 11 males, 19 females, 16 children, 2 adults; Table 1; Melis/Hajdu 2017). In some cases the preservation of human remains was so poor that determination of age among adults was not possible, thus out of all burials only 10 maturus or matures-senior individuals could be identified (over the age of 40).

\section{FUNERARY CYCLE \\ AND POST-FUNERARY FORMATION PROCESSES IN THE CEMETERY}

Similarly to other Gáta-Wieselburg burial grounds, the dominance of the inhumation tradition is reflected clearly by the burials at Hegyeshalom (Krenn-Leeb 2011). There was only one exception: burial No. 56, which contained the unburnt skeletal remains of a child, along with the cremated remains of an individual aged between 8 and 30. Considering the round shape of the grave pit, it is possible that the burial was reopened at a later stage, as the dominant burial custom at the cemetery appears to be inhumations placed in rectangular or ovoid graves. The length of the graves was generally around 1-2 metres, their width around 0.5-1 metres with the depth of 0.5 to 1.5 metres. Burial No. 26 represented the deepest burial of the cemetery, and because of later reopening, it only contained a few bone fragments (Table 1). Traces of wooden coffins, as documented at other Gáta-Wieselburg cemetery sites, could not be observed at Hegyeshalom (Gömöri/Melis/Kiss 2018, 48; Krenn-Leeb 2011, fig. 24; Nagy $2013,93,94)$, although in the case of burial No. 52, the leader of the excavation assumed the presence of a coffin based on the arrangement of the human remains and grave goods.

At Hegyeshalom along with the SW-NE orientation typical of the Gáta-Wieselburg culture, some burials were oriented slightly towards the W-E axis. This trend is generally reflective of the GátaWieselburg cemeteries in Hungary (Melis 2017; 2020). At Hegyeshalom most of the bodies were flexed and placed on their side. The number of individuals placed deliberately on their right side (16) is double of the bodies placed on their left (8), indicating that even men were dominantly placed on their right side for burial. This loosening adherence to a tradition that regulated the deposition of bodies according to their gender could reflect a community of people coming together from different backgrounds. However, a similar process can also be observed in cemeteries during the Early Bronze Age, perhaps due to changing gender roles at this time (Sosna 2009, 136, 137).

Beside intense recent disturbances at Hegyeshalom at least $36 \%$ of the burials (21 graves) were deliberately reopened sometime in the past, affecting mainly male and female burials (Table 2; Fig. 3: a; Melis 2017; Melis, in print). Over half of the male burials were reopened, as opposed to only two (No. 45,56$)$ intentionally disturbed child burials. The disturbance predominantly affected areas of the skull, the upper body and the arms, but the manipulation of the entire body is not rare either, which could be indicative of a multi-stage mortuary process (Weiss-Krejci 2011). Given the absence of bronze artefacts in disturbed graves, it is likely that the reason behind such reopenings were the targeted removal of bronze objects. However, in a couple of cases, the deposition of a consecutive burial could also be observed (No. 43A, 56) while missing body parts could hint at a continued ritual interaction with the deceased (Kümmel 2009, 82-95).

\section{GRAVE FURNITURE}

Thus far, detailed description of few grave goods (No. 5, 9 and 21) have been published from Hegyeshalom as part of larger studies on ornaments (Nagy/ Figler 2009, 257-260, fig. 1; 2; Szathmári 1988, 68-70, fig. 8). The complete overview and publication of the entire burial material forms a part of my forthcoming doctoral thesis. Altogether 207 pieces of grave goods were recovered from the burials (Table 1), a significant proportion of which is ceramic vessels (93 pieces). These were most often cups, small cooking pots, jugs with two handles, and less frequently amphoras and bowls, all characteristic ceramic types of the Gáta-Wieselburg assemblages. Generally, one or two ceramic pieces were deposited in each grave (in 23 instances), but in two adult burials, seven and eight vessels were placed beside the deceased. In $38 \%$ of the burials ceramic vessels represented the sole grave furniture.

Despite of the intense disturbance of the burials in the cemetery, bronze artefacts were documented in 16 graves ( $28 \%$ of burials), altogether 101 pieces (Table 1; Fig. $1 ; 2)$. The majority of these were tubular spiral beads coiled from bronze wire (65 pieces) which 
Table 2. Sex, age, disturbance type of the graves and Social Indices at Hegyeshalom-Újlakótelep. Age indicates osteologically determined age, in some cases, the excavation diary suggests the young age of the deceased (in brackets).

\begin{tabular}{|c|c|c|c|c|c|c|c|c|c|}
\hline Grave No. & $\begin{array}{l}\text { Sex (gen- } \\
\text { der) }\end{array}$ & Age & Disturbance & $\begin{array}{l}\text { Grave } \\
\text { depth } \\
\text { index }\end{array}$ & $\begin{array}{l}\text { Grave } \\
\text { good } \\
\text { count } \\
\text { index }\end{array}$ & $\begin{array}{l}\text { Grave } \\
\text { good } \\
\text { diversity } \\
\text { index }\end{array}$ & $\begin{array}{c}\text { Material } \\
\text { index }\end{array}$ & $\begin{array}{l}\text { Associa- } \\
\text { tion index }\end{array}$ & $\begin{array}{l}\text { Social } \\
\text { index }\end{array}$ \\
\hline 001 & - & Juv. & undisturbed & 39 & 8 & 17 & 20 & 2 & 19 \\
\hline 002 & - & (child) & $\begin{array}{l}\text { recently } \\
\text { disturbed }\end{array}$ & 50 & 0 & 0 & 0 & 0 & 11 \\
\hline 003 & male & Ad.-mat. & $\begin{array}{l}\text { intentional } \\
\text { re-opened }\end{array}$ & 50 & 11 & 17 & 20 & 3 & 22 \\
\hline 004 & - & - & $\begin{array}{l}\text { empty } \\
\text { gravepit }\end{array}$ & 68 & 0 & 0 & 0 & 0 & 15 \\
\hline 005 & female & Ad. & undisturbed & 58 & 100 & 100 & 100 & 100 & 100 \\
\hline 006 & - & Ad.-sen. & $\begin{array}{l}\text { intentional } \\
\text { re-opened }\end{array}$ & 74 & 22 & 17 & 20 & 16 & 33 \\
\hline 007 & - & Inf. I-II & undisturbed & 47 & 14 & 17 & 20 & 3 & 22 \\
\hline 008 & - & $0-1$ & undisturbed & 55 & 6 & 33 & 40 & 1 & 29 \\
\hline 009 & female & Ad.-mat. & $\begin{array}{l}\text { recently } \\
\text { disturbed }\end{array}$ & 47 & 36 & 67 & 40 & 18 & 45 \\
\hline 010 & - & - & $\begin{array}{l}\text { recently } \\
\text { disturbed }\end{array}$ & - & 3 & 17 & 20 & 1 & 11 \\
\hline 011 & - & - & $\begin{array}{l}\text { recently } \\
\text { disturbed }\end{array}$ & - & - & - & - & - & - \\
\hline 012 & - & - & $\begin{array}{l}\text { recently } \\
\text { disturbed }\end{array}$ & - & - & - & - & - & - \\
\hline 013 & - & - & $\begin{array}{l}\text { recently } \\
\text { disturbed }\end{array}$ & - & - & - & - & - & - \\
\hline 014 & female & Ad.-mat. & $\begin{array}{l}\text { recently } \\
\text { disturbed }\end{array}$ & 53 & 0 & 0 & 0 & 0 & 12 \\
\hline 015 & - & - & $\begin{array}{l}\text { recently } \\
\text { disturbed }\end{array}$ & - & - & - & - & - & - \\
\hline 016 & - & - & $\begin{array}{l}\text { recently } \\
\text { disturbed }\end{array}$ & - & - & - & - & - & - \\
\hline 017 & - & - & $\begin{array}{l}\text { recently } \\
\text { disturbed }\end{array}$ & - & - & - & - & - & - \\
\hline 018 & - & - & $\begin{array}{l}\text { recently } \\
\text { disturbed }\end{array}$ & - & - & - & - & - & - \\
\hline 019 & female & Mat. & undisturbed & 47 & 11 & 17 & 20 & 3 & 21 \\
\hline 020 & female & Ad.-sen. & $\begin{array}{l}\text { intentional } \\
\text { re-opened }\end{array}$ & 39 & 8 & 33 & 40 & 3 & 27 \\
\hline 021 & female & Ad. & undisturbed & - & 97 & 67 & 60 & 64 & 79 \\
\hline 022 & male & Mat. & $\begin{array}{l}\text { intentional } \\
\text { re-opened }\end{array}$ & 50 & 3 & 17 & 20 & 1 & 20 \\
\hline 023 & male & Mat. & $\begin{array}{l}\text { intentional } \\
\text { re-opened }\end{array}$ & 42 & 3 & 17 & 20 & 3 & 19 \\
\hline 024 & male & Mat. & undisturbed & 32 & 8 & 33 & 20 & 6 & 22 \\
\hline 025 & - & (child) & undisturbed & 26 & 3 & 17 & 20 & 1 & 15 \\
\hline 026 & - & Ad.-sen. & $\begin{array}{l}\text { intentional } \\
\text { re-opened }\end{array}$ & 100 & 17 & 50 & 40 & 8 & 47 \\
\hline 027 & female & Ad.-sen. & $\begin{array}{l}\text { intentional } \\
\text { re-opened }\end{array}$ & 79 & 8 & 33 & 40 & 4 & 36 \\
\hline 028 & male & Ad.-mat. & undisturbed & 47 & 6 & 17 & 40 & 1 & 24 \\
\hline 029 & - & - & $\begin{array}{l}\text { empty } \\
\text { gravepit }\end{array}$ & 53 & 0 & 0 & 0 & 0 & 12 \\
\hline 030 & female & Ad. & $\begin{array}{l}\text { intentional } \\
\text { re-opened }\end{array}$ & 39 & 0 & 0 & 0 & 0 & 9 \\
\hline 031 & male & Mat. & $\begin{array}{l}\text { recently } \\
\text { disturbed }\end{array}$ & 58 & 11 & 67 & 40 & 4 & 39 \\
\hline 032 & - & $7-8$ & undisturbed & 42 & 0 & 0 & 0 & 0 & 9 \\
\hline
\end{tabular}


Table 2. Continued.

\begin{tabular}{|c|c|c|c|c|c|c|c|c|c|}
\hline Grave No. & $\begin{array}{l}\text { Sex (gen- } \\
\text { der) }\end{array}$ & Age & Disturbance & $\begin{array}{l}\text { Grave } \\
\text { depth } \\
\text { index }\end{array}$ & $\begin{array}{l}\text { Grave } \\
\text { good } \\
\text { count } \\
\text { index }\end{array}$ & $\begin{array}{l}\text { Grave } \\
\text { good } \\
\text { diversity } \\
\text { index }\end{array}$ & $\begin{array}{c}\text { Material } \\
\text { index }\end{array}$ & $\begin{array}{l}\text { Associa- } \\
\text { tion index }\end{array}$ & $\begin{array}{l}\text { Social } \\
\text { index }\end{array}$ \\
\hline 033 & female & Ad.-sen. & $\begin{array}{l}\text { intentional } \\
\text { re-opened }\end{array}$ & 37 & 11 & 17 & 20 & 3 & 19 \\
\hline 034 & male & Ad.-sen. & $\begin{array}{l}\text { intentional } \\
\text { re-opened }\end{array}$ & 37 & 19 & 17 & 20 & 5 & 21 \\
\hline 035 & male & Ad.-mat. & $\begin{array}{l}\text { intentional } \\
\text { re-opened }\end{array}$ & 66 & 6 & 33 & 40 & 2 & 32 \\
\hline 036 & - & - & $\begin{array}{l}\text { intentional } \\
\text { re-opened }\end{array}$ & 61 & 6 & 17 & 20 & 1 & 23 \\
\hline 037 & female & Mat.-sen. & undisturbed & & 0 & 0 & 0 & 0 & \\
\hline 038 & female & Mat. & undisturbed & 37 & 6 & 17 & 20 & 2 & 18 \\
\hline 039 & female & Juv. & $\begin{array}{l}\text { intentional } \\
\text { re-opened }\end{array}$ & 61 & 14 & 50 & 60 & 5 & 41 \\
\hline 040 & male & Mat. & undisturbed & 58 & 6 & 17 & 20 & 1 & 22 \\
\hline 041 & female & $14-40$ & $\begin{array}{l}\text { intentional } \\
\text { re-opened }\end{array}$ & 45 & 8 & 33 & 40 & 3 & 28 \\
\hline 042 & - & $4-8$ & undisturbed & 29 & 0 & 0 & 0 & 0 & 6 \\
\hline 043A & - & Inf. I-II & undisturbed & 26 & 0 & 0 & 0 & 0 & 6 \\
\hline 043B & - & \pm 4 & undisturbed & 39 & 0 & 0 & 0 & 0 & 9 \\
\hline 044 & - & 9 & undisturbed & 42 & 0 & 0 & 0 & 0 & 9 \\
\hline 045 & - & $11-12$ & $\begin{array}{l}\text { intentional } \\
\text { re-opened }\end{array}$ & 68 & 19 & 50 & 40 & 6 & 40 \\
\hline 046 & female & Mat. & $\begin{array}{l}\text { intentional } \\
\text { re-opened }\end{array}$ & 34 & 8 & 33 & 40 & 2 & 26 \\
\hline 047 & female & Ad.-sen. & $\begin{array}{l}\text { intentional } \\
\text { re-opened }\end{array}$ & 58 & 22 & 17 & 20 & 5 & 27 \\
\hline 048 & - & (child) & undisturbed & 45 & 0 & 0 & 0 & 0 & 10 \\
\hline 049 & male & Ad.-sen. & $\begin{array}{l}\text { intentional } \\
\text { re-opened }\end{array}$ & 63 & 19 & 50 & 40 & 7 & 39 \\
\hline 050 & - & (child) & $\begin{array}{l}\text { recently } \\
\text { disturbed }\end{array}$ & 45 & 6 & 17 & 20 & 1 & 19 \\
\hline 051 & female & $18-22$ & $\begin{array}{l}\text { intentional } \\
\text { re-opened }\end{array}$ & 45 & 3 & 17 & 20 & 1 & 19 \\
\hline 052 & female & Ad.-mat. & undisturbed & 45 & 14 & 17 & 20 & 3 & 22 \\
\hline 053 & male & Mat. & undisturbed & 68 & 6 & 17 & 20 & 1 & 24 \\
\hline 054 & female & Ad. & $\begin{array}{l}\text { intentional } \\
\text { re-opened }\end{array}$ & 58 & 3 & 17 & 20 & 1 & 22 \\
\hline 055 & female & Ad.-mat. & undisturbed & 13 & 6 & 17 & 20 & 1 & 12 \\
\hline 056 & - & $\begin{array}{c}5-10+ \\
\text { cremated } \\
\text { bones of an } \\
8-30- \\
\text {-year-old } \\
\text { individual }\end{array}$ & $\begin{array}{l}\text { intentional } \\
\text { re-opened }\end{array}$ & 37 & 3 & 17 & 20 & 1 & 17 \\
\hline 057 & - & $4-5$ & undisturbed & 68 & 6 & 17 & 20 & 1 & 24 \\
\hline 058 & - & (child) & undisturbed & 53 & 3 & 17 & 20 & 1 & 21 \\
\hline Average & - & - & - & 49.583 & 11.098 & 22.353 & 23.137 & 5.765 & 24.660 \\
\hline
\end{tabular}

concentrated in two female burials (No. 5 and 21) worn probably as an intricate, multi-strand necklace or collar. However, if we interpret the spiral beads in the same grave as part of a large, single ornament on the neck or chest, there could only be 43 pieces of bronze artefacts counted from the cemetery.
Tubular spiral beads were often combined with beads of dentalium shells as a composite ornament (Fig. 2: 15). The four spectacle spirals and a stud recovered from a female burial (No. 9) could have been part of a garment, headdress or veil (Fig. 2: 11, 12). Small bronze wire rings twisted multiple times 


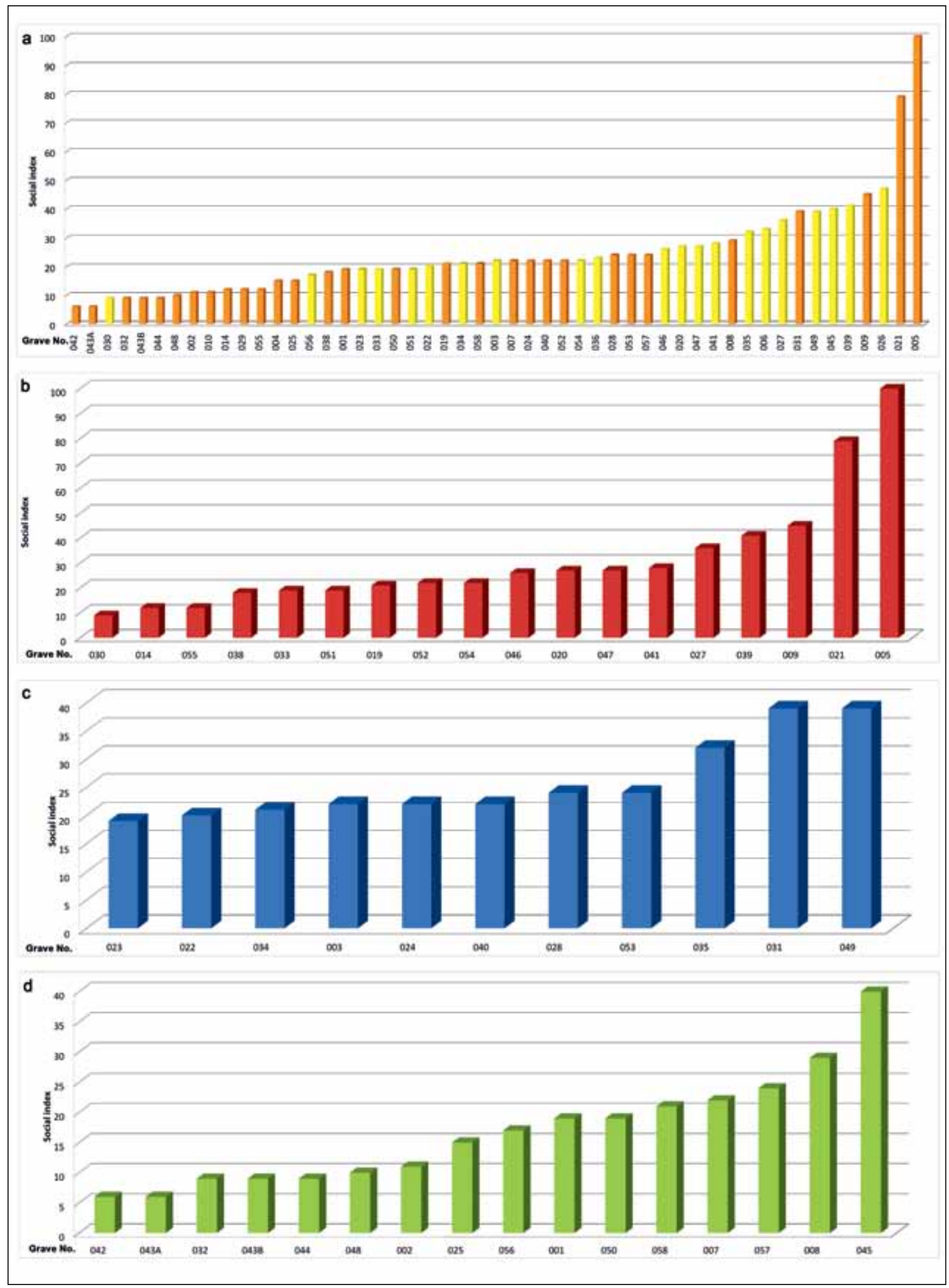

Fig. 3. Graphs of the combined Social Index calculations of Hegyeshalom-Újlakótelep. a - all of the identifiable graves (reopened burials marked yellow); $\mathrm{b}$ - female burials; $\mathrm{c}$ - male burials; $\mathrm{d}$ - child burials. 
(Noppenring) are known from eight female and one male burial placed around the skull (Fig. 2: 1-3), and two larger hair- or ear-rings were found in female burial No. 38 (Fig. 2: 4). Fragments of spiral arm-rings were unearthed from two child burials (Fig. 2: 9, 10). Pins however, occur exclusively in adult burials: at Hegyeshalom, altogether four Cypriot pins (Schleifenkopfnadel) were placed in two female and two male burials (Fig. 2: 5-8). From a grave of a woman (No. 5) at the head of the pin, an amber bead (Fig. 2: 13) was documented, implying that the two objects could have been joined together originally. The most spectacular grave goods were discovered in a male burial (No. 31): a bronze pin, a neck-ring and dagger - the only weapon represented in the cemetery (Fig. 2: 5, 14, 16). The bronze artefacts occurring in the cemetery overall are typical Early Bronze Age examples characteristic of the Central Danubian region.

Furthermore, based on the excavation documentation, in cases of a few, mainly female burials, organic residues could also be observed. In burial No. 5, leather fragments were recorded underneath the tubular spiral beads on the neck/chest area, while in a further three burials which were later reopened, black discolouration was noted in the place of the skull. In a male burial (No. 35) a charred object was found, resembling a shovel.

Bronze artefacts can also leave a distinct trace on human remains, which is particularly discernible in cases of reopened burials from where such objects were removed: under the supervision of the anthropologist Tamás Hajdu, we were able to identify human remains, where green discolouration was detected on the bones due to close proximity to a bronze artefact now absent from the grave (Melis/ Hajdu 2017). The possible reconstructions of these grave goods are ongoing, and will soon be published as a co-authored paper.

Ten grave pits containing human remains did not have any grave goods, all these graves belonged either to children or women. However, due to modern disturbance, another ten graves contained neither human remains, nor grave goods.

\section{THE EXAMINATION OF SOCIAL STRUCTURE WITHIN THE CEMETERY OF HEGYESHALOM}

Since the cemetery of Hegyeshalom has been exposed to large-scale disturbance, a categorisation of its burials based chiefly on the number and material of grave goods is likely to produce inaccurate results, along with any conclusions drawn in terms of the social status of the deceased. Instead, in Aus- tria, for the examination of similarly reopened Early Bronze Age burials, the method of the so-called Combined Social Index Calculation was applied to assess the 'value' of individual burials in the context of the cemetery as a whole (Sprenger 1999, 67-96). The method of Social Index Calculation ascribes a value between 1 and 100 to each burial in order to express the social ranking of the deceased based on the qualitative and quantitative evaluation of certain chosen characteristics. Although, this of course cannot reflect the exact situation in the past, but it could potentially provide a useful tool for the archaeological interpretation. Since the method involves elements independent of the number and material of grave goods, it can be applied in the case of reopened burials with the clause that the variables related to grave goods represent minimum values (Rebay-Salisbury et al. 2018, 79-83).

In this study, five variables were considered for the calculation of the combined Social Index: 1) grave depth index, 2) grave good count index, 3) grave good diversity index, 4) material index and 5) association index, in a similar way as in the case of the cemetery of Unterhautzenthal associated with the Únětice culture (Table 2; Rebay-Salisbury et al. 2018, table 4). For the index calculation of variables, the burial with the highest value were given the score of 100, according to which the rest of the burials were valued proportionately between 1 and 100. For the calculation of the grave depth index the (highest) value of 100 was given to burial No. 26, where the grave was $1.9 \mathrm{~m}$ deep, while burial No. 55 representing the shallowest grave with a depth of $0.25 \mathrm{~m}$ was given the value of 13. Hence, the average value of grave depth index at Hegyeshalom was quite high (49.58).

The largest number of grave goods were discovered in burial No. 5 , a female burial (containing 36 pieces of artefacts - grave good count index: 100), while burial No. 21 (also a female burial) contained 35 pieces (grave good count index: 97). Since - apart from the two above mentioned graves - in average the number of grave goods were below 10 pieces in the cemetery as a whole, the average grave good count index comes to 11 . The highest diversity of grave goods, six different artefact types were recorded in burial No. 5, representing 100 as a value for grave good diversity index. There was little variety in terms of the material of grave goods (bronze, dentalium shells, amber, ceramic and organic matter), here again burial No. 5 represented the value of a 100. Burials which contained goods made of identical material were given the value of 20 .

The calculation of the association index is based on the method whereby the value of a given grave good type can be expressed by the average number of other goods discovered from the same grave. The 


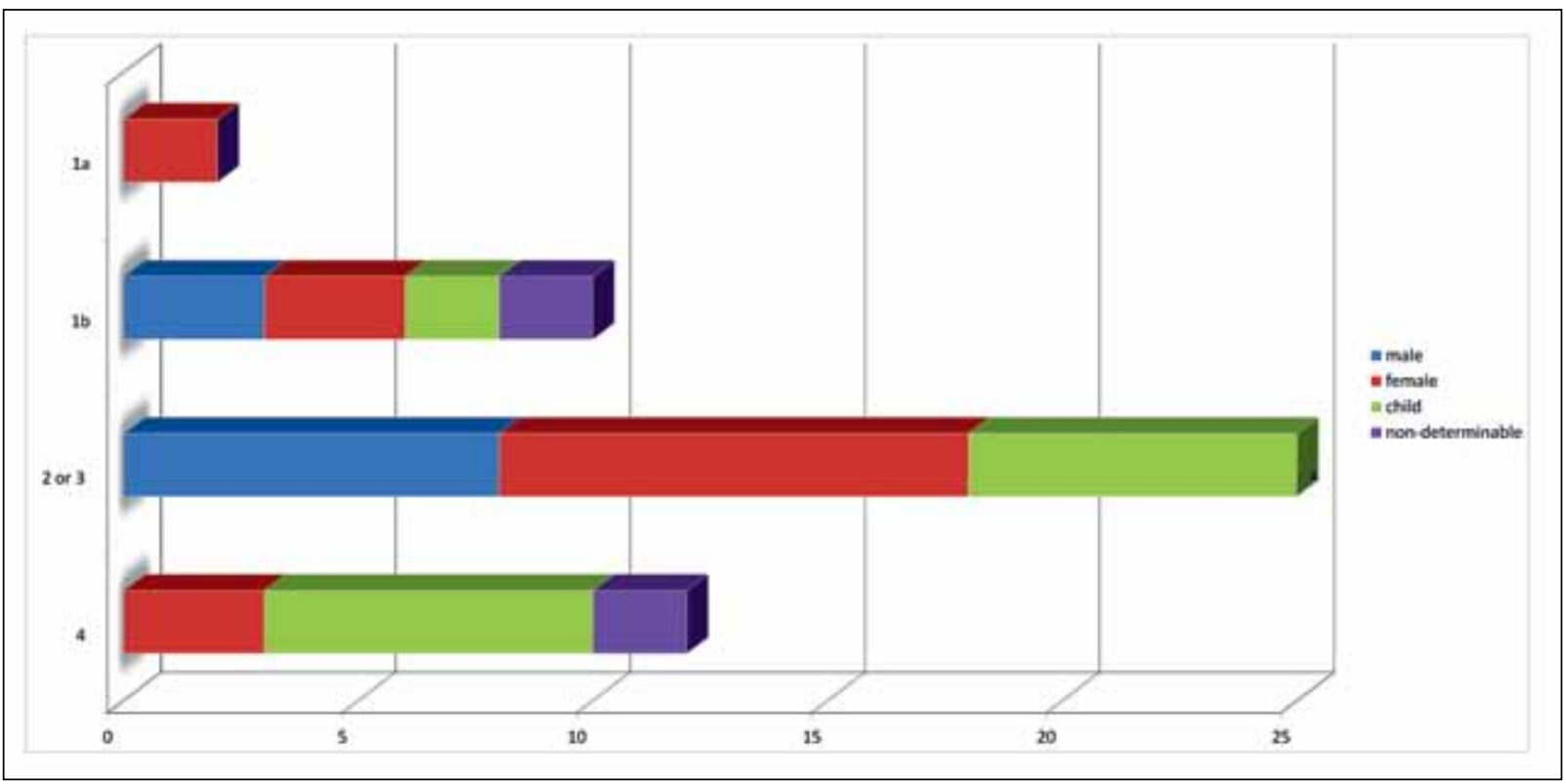

Fig. 4. Proportions of age and gender of the identified social categories at Hegyeshalom-Újlakótelep.

first row of Table 1 contains - in brackets following the object types - this value. The association index of any given burial is calculated by the sum of its grave goods' association index value relative to a 100. For example, the sum of burial No. 5's association indices is above 500 (its own association index: 100), therefore other burials which contained objects with indices below 5 , have their association index calculated to 1 . At the Hegyeshalom cemetery as a whole, the average of association index was remarkably low (5.77).

The average of the five variables was the highest in the case of burial No. 5 given the large number and the variety of its grave goods, thus was the only burial in the cemetery that represented the combined Social Index of a 100. Burial No. 21 was not far behind with a Social Index of 79, especially since the grave depth index was not available in this case (Fig. 3: a, b). These two outstanding burials were found undisturbed, however the third highest combined Social Index was associated with burial No. 26, which was later reopened and according to the documentation, a large part of its contents were removed.

Looking at the combined Social Index values from the perspective of gender, it is clear that in the Hegyeshalom cemetery male burials even with the highest social indices (No. 31, 49, 35) fall behind the female burials (Fig. 3: c). However, compared to the rest of the male burials, it is likely that the above mentioned three graves represented male members of the elite. Among the burials of children, the highest combined Social Index score was associated with an intentionally reopened burial of a child aged 11-12 (No. 45; Fig. 3: d). Generally, if a male, female or unidentifiable burial had a Social Index value over 30 , it is likely that these individuals belonged to higher echelons of the society. Altogether 11 burials had a Social Index score over 30 out of which seven were reopened. Considering that the combined Social Index of burial No. 8 - a child burial - was significantly higher than the rest of the child burials, it is feasible to assume that this infant buried with a bronze spiral arm-ring could have belonged to a family of high social status.

On the graph showing the overall Combined Social Index values, burials with scores below 12 seem to form a cluster of their own; these could have been associated with individuals of low social status, mostly children and three women (Fig. 3).

Burials with Social Index values between 12 and 30 have little distinguishing factors between them, a gradual increase in values can be observed as it is shown on the cumulative chart (Fig. 3: a). However, if we look at the graphs showing Social Index values separately according to gender (Fig. 3: b, c), there are some observable differences: in case of both male and female burials there is a break around the Social Index value of 22, burials above this score could have belonged to the upper levels of the 'middle class'. A little over half of the burials below the Social Index value of 22 were left undisturbed. When it comes to children's burials, it is even more difficult to define the upper layers of the middle classes, since bronze grave goods were mainly absent. However, the young individuals buried in No. 7, 57 and 58 most likely belonged to the upper levels of the middle class (Fig. 3: d). 
Although there were no grave goods made of gold documented at Hegyeshalom, the two outstandingly rich female burials can be compared with the individuals of the highest social status identified at the Gáta-Wieselburg cemeteries of Nagycenk and Zsennye (category 1a; Fig. 4) Among the burials associated with the elite (category $1 \mathrm{~b}$ ) whose graves were often reopened and had high Combined Social Index values - a further three men, three women, two children and two adult individuals can be identified. The highest social category at Hegyeshalom was represented by $3 \%$ of the population (two female graves), whereas $17 \%$ of the burials could have belonged to high status elites. Among the 'middle class' burials, both in the case of males and females (category 2-3) the rate of grave reopenings is high which resulted in the blurring of the boundaries between levels of social status within this category. There appears to be a correlation between burials of low Social Index and a decreased ratio of intentional grave disturbance. The majority of male burials (eight cases) belongs to the categories of the middle class, along with over half of the female burials (ten cases). Apart from the two high status child burials, half of the children's burials were representative of the middle classes (seven cases), while the other half contained burials of children of the lowest social status (seven cases). $21 \%$ of the cemetery's population had low Social Index values (category 4).

\section{CONCLUSIONS}

Examinations carried out on the Gáta-Wieselburg burials from Hungary have shown that the social representation and the expression of social identity was an important factor during the funerary cycle including both genders and less frequently, children as well. Although at Hegyeshalom the burials of children did not generally contain grave goods, burial No. 45 of a child at age of 11-12 years - despite the intentional later disturbance - contained four bronze hair-rings, fragments of an arm-ring, along with green patina traces detected on the bones. These grave goods and the traces left by bronze objects can be compared with burial No. 53 at Nagycenk, where the undisturbed remains of a child of similar age (10-12 years) were excavated, accompanied by a gold and a bronze hair-ring, a thin neck-ring, a spiral arm-ring and an intricate, multistrand necklace consisting of bronze spiral tubes and dentalium shells (Gömöri/Melis/Kiss 2018, fig. 5).

However, at Hegyeshalom it was not representative of maturus adults to be buried without grave goods as it was recorded at Zsennye (Nagy 2013,
$116,117)$, or at the cemeteries associated with the Transdanubian Encrusted Pottery culture (Kiss 2012, 248-255; Dani et al. 2016): out of the burials of ten maturus adults, four contained bronze grave goods and two were later reopened. The burial of a male reflecting high status (No. 31) accompanied by a dagger and a neck-ring could have belonged to an individual over the age of 40 . In the case of elite female burials where the aging of the skeletons could be carried out with more certainty, young adult and adult women (under the age of 40) were identified (No. 5, 21, 39), nevertheless one or two hair-rings occurred in burials of older women (No.38, 46) as well.

The bronze grave goods furnishing the burials of adults aged over 40 years with higher Social Index scores imply the that these individuals were able to achieve high social status through their personal and/or economic prowess, hinting towards the existence of a 'big man' type social model. The richness of young adult and adult female burials could indicate the custom of bridewealth for married or to be married women within the community, a way through which families' economic power could be asserted (Bösel 2008, 101-105; Sosna 2009, tab. 4.1-4.5). More recently, the genetic analyses carried out on Early Bronze Age cemeteries in Southern Germany have shown the kinship-based organisation of the local elite, sketching out a social organisation similar to what is described by the 'great man' model. In these cemeteries, contemporaneous with Hegyeshalom, however, the archaeological evidence was not substantial enough to support the political-ideological power wielded by a single family (Mittnik et al. 2019).

The deposition of bronze objects, shell and amber artefacts and their removal during later reopenings of graves outlines the presence of sizeable elite at Hegyeshalom, some of whom actively sought to transfer their social and/or economic power to their descendants, testified by the rich burials of children (Sosna 2009, 131). The occurrence of high status children's burials brings up the issue of institutionalization of vertical social hierarchies (Bösel 2008; Sosna 2009, 140-142). The question how a complex process, which resulted in the emergence of chiefdoms, can be reconstructed in the Gáta-Wieselburg communities, can only be answered by the analysis and comparison of further large-scale cemeteries and settlements in the region of Western Hungary, Eastern Austria and Southwestern Slovakia.

\section{Acknowledgements}

The material of the Hegyeshalom cemetery is curated by the Museum of Hanság at Mosonmagyaróvár (65.2.1-65.37.2.1; 66.2.1.1-66.4.2.1; 74.7.1-74.7.8). Here I would like to thank Tamás Czuppon, who helped me 
with researching in the museum. The human remains are now catalogued and kept at the Department of Anthropology at the Hungarian Museum of Natural History in Budapest (68.120.1-43.). I would like to express my gratitude to colleagues at the Department and to Tamás Hajdu and Kitti Köhler for completing the latest anthropological examinations.

This paper and my ongoing PhD study (entitled: Northwestern Transdanubia between the End of the Early Bronze Age and the Koszider Period, supervised by Gábor V. Szabó, Eötvös Loránd University) was supported by the Momentum Mobility research project hosted by the Institute of Archaeology, Research Centre for the Humanities (Principal investigator: Viktória Kiss). Furthermore I am also grateful to Borbála Nyíri for her help with the English translation and valuable comments on the article.

\section{LITERATURE}

Aspöck 2015 - E. Aspöck: Cross-cultural interpretations and archaeological context. A reopened Early Bronze Age grave in Weiden am See, Austria. In: L. Gardeła/ K. Kajkowski (red.): Kończyny, kości i wtórnie otwarte groby $w$ dawnych kulturach = Limbs, Bones, and Reopened Graves in Past Societies. International Interdisciplinary Meetings: Motifs Throught The Ages 2. Bytów 2015, 22-43.

Bösel 2008 - M. Bösel: Wandel durch Bronze? - Vergleichende Untersuchung sozialer Strukturen auf früh- und mittelbronzezeitlichen Gräberfeldern im Theißgebiet. Prähistorische Zeitschrift 83, 2008, 45-108.

Dani et al. 2016 - J. Dani/K. P. Fischl/V. Kiss/G. Kulcsár/ V. Szeverényi: Visible and Invisible Inequality: Changing Patterns of Wealth Consumption in Early and Middle Bronze Age Hungary. In: H. Meller/H. P. Hahn/R. Jung/R. Risch (Hrsg.): Arm und Reich - Zur Ressourcenverteilung in prähistorischen Gesellschaften. 8. Mitteldeutscher Archäologentag vom 22. bis 24. Oktober 2015 in Halle (Saale). Tagungen des Landesmuseums für Vorgeschichte Halle 14-1. Halle 2016, 33-48.

Earle/Kristiansen 2010 - T. Earle/K. Kristiansen: Organizing Bronze Age Societies. The Mediterranean, Central Europe and Scandinavia Compared. Cambridge 2010.

Fischl et al. 2015 - K. P. Fischl/V. Kiss/G. Kulcsár/V. Szeverényi: Old and new narratives for the Carpathian Basin around 2200 BC. In: H. Meller/W.-H. Arz/ R. Jung/R. Risch (eds.): 2200 BC - A climatic breakdown as a cause for the collapse of the old world? $7^{\text {th }}$ Archaeological Conference of Central Germany. October 23-26, 2014 in Halle (Saale). Tagungen des Landesmuseums für Vorgeschichte Halle 12-2. Halle 2015, 503-523.

Gömöri/Melis/Kiss 2018 - J. Gömöri/E. Melis/V. Kiss: The cemetery of the Bronze Age Gáta-Wieselburg culture at Nagycenk (western Hungary). Acta Archeologica Academiae Scientiarum Hungaricae 69, 2018, 5-82.

HNM Archives XXIII 312/1966 - R. Pusztai: Hegyeshalom-Újlakótelep (Győr-Moson-Sopron megye). Pusztai Rezső 1965. évi leletmentése - gátai kultúrás temető. Hungarian National Museum, Archaeological Archives XXIII 312/1966 (documentation).

HNM Archives V 91/1967 - R. Pusztai: Hegyeshalom-Újlakótelep. Gátai típusú temetôl leletmentő ásatása 1966. (54-58. sírok). Hungarian National Museum, Archaeological Archives V 91/1967 (documentation).

Kienlin 2015 - T. Kienlin: Bronze Age Tell Communities in Context. An exploration into culture, society, and the study of European prehistory 1 - Critique: Europe and the Mediterranean. Oxford 2015.
Kiss 2012 - V. Kiss: Middle Bronze Age Encrusted Pottery in western Hungary. Varia Archaeologica Hungarica 27. Budapest 2012.

Kiss 2020 - V. Kiss: The Bronze Age burial from Balatonakali revisited. In: J. Maran/A. Sorin-Christian/R. Bajenaru/ S. Hansen (eds.): Objects, Ideas and Travelers. Contacts between the Balkans, the Aegean and Western Anatolia during the Bronze Age and Early Iron Age. Conference to the Memory of Alexandru Vulpe. $10^{\text {th }}-13^{\text {th }}$ November 2017, Tulcea, Romania. Tulcea 2020, 553-568.

Krenn-Leeb 2011 - A. Krenn-Leeb: Zwischen Buckliger Welt und Kleinen Karpaten - Die Lebenswelt der Wieselburg-Kultur. Archäologie Österreichs 22, 2011, 11-26.

Kümmel 2009 - C. Kümmel: Ur- und frühgeschitlicher Grabraub. Archäologische Interpretation und kulturanthropologische Erklärung. Tübinger Schriften zur Ur- und Frühgeschitlichen Archäologie 9. Münster - New York - München 2009.

Mali 2014 - P. Mali: Biatorbágy-Szarvasugrás középső bronzkori temetője. In: A. Rajna (szerk.): Múltunk a föld alatt. Újabb régészeti kutatások Pest megyében. = Our Past under Earth. Recent Archaeological Investigations In Pest County. Szentendre 2014, 23-49, 170, 185-201.

Melis $2017-$ E. Melis: Analysis of secondary mortuary practices in the Early Bronze Age inhumation burials from NorthWestern Hungary. Musaica archaeologica 2/1, 2017, 7-22.

Melis 2020 - E. Melis: A nemi identitás kifejezésének vizsgálata a Nyugat-Dunántúl kora és középső bronzkori csontvázas temetkezései körében. In: P. Csengeri/A. Kalli/Á. Király/J. Koós J. (szerk.): $M \Omega M O \Sigma I X$. A rituálé régészete. Öskoros Kutatók IX. Összejövetelének konferenciakötete Miskolc, 2015. október 14-16. Dissertationes Archaeologicae. Supplementum 3. Budapest 2020, 75-99.

Melis, in print - E. Melis: Temetkezési szokások a Gáta-Wieselburg kultúra hegyeshalmi temetőjében (Mortuary practices in the cemetery of Hegyeshalom from the Gáta-Wieselburg culture). In: G. Nemes (szerk.): Köszöntő kötet Tomka Péter 80. születésnapjára. Győr, in print.

Melis/Hajdu 2017 - E. Melis/T. Hajdu: Analysis of secondary mortuary practices in Early Bronze Age inhumation burials from North-western Hungary. In: J. Bazelmans (ed.): Building Bridges: Abstract book of the 23 $3^{\text {rd }}$ Annual Meeting of the European Association of Archaeologists 2017. Maastricht 2017, 138.

Meller 2017 - H. Meller: Armies in the Early Bronze Age? An alternative interpretation of Únětice culture axe hoards. Antiquity 91, 2017, 1529-1545. 
Mittnik et al. 2019 - A. Mittnik/K. Massy/C. Knipper/ F. Wittenborn/S. Pfrengle/N. Carlichi-Witjes/H. Deeg/ A. Furtwängler/M. Harbeck/K. V. Heyking/ C. Kociumaka/I. Kucukkalipci/S. Lindauer/S. Metz/ A. Staskiewicz/A. Thiel/J. Wahl/W. Haak/E. Pernicka/ S. Schiffels/P. W. Stockhammer/J. Krause: Kinshipbased social inequality in Bronze Age Europe. Science 366, 2019, 731-734.

Nagy 2013 - M. Nagy: Der südlichste Fundort der GátaWieselburg-Kultur in Zsennye-Kavicsbánya/Schottergrube, Komitat Vas, Westungarn. Savaria 36, 2013, 75-173.

Nagy/Figler 2009 - M. Nagy/A. Figler: Dentáliumékszerek a Gáta-Wieselburg kultúra temetkezéseiben. In: G. Ilon (szerk.): $M \Omega M O \Sigma$ VI. Nyersanyagok és kereskedelem. Öskoros Kutatók VI. Összejövetelének konferenciakötete -Köszeg, 2009. március 19.-21. Szombathely 2009, 255-266. Rebay-Salisbury et al. 2018 - K. Rebay-Salisbury/D. Pany-Kucera/M. Spannagl-Steiner/F. Kanz/P. Galeta/R. B.
Salisbury: Motherhood at Early Bronze Age Unterhautzenthal. Archaeologia Austriaca 102, 2018, 71-134.

Sosna 2009 - D. Sosna: Social Differentiation in the Late Copper Age and the Early Bronze Age in South Moravia, Czech Republic. BAR 1994. Oxford 2009.

Sprenger 1999 -S. Sprenger: Zur Bedeutung des Grabraubes für sozioarchäologische Gräberfeldanalysen. Eine Untersuchung am frühbronzezeitlichen Gräberfeld Franzhausen I, Niederösterreich. Fundberichte aus Österreich. Materialhefte A/7. Wien 1999.

Szathmári 1988 - I. Szathmári: Korai tűtipusok a bronzkorban a Dunántúlon. Folia Archaeologica 39, 1988, 59-80.

Weiss-Krejci 2011 - E. Weiss-Krejci: The formation of mortuary deposits: implications for understanding mortuary behaviour of past populations. In: S. C. Agarwal/B. Glencross (eds.): Social Bioarchaeology. Chichester 2011, 68-106.

Zoffmann 1999 - Zs. K. Zoffmann: A bronzkori Gáta-Wieselburg kultúra embertani leletei Hegyeshalom-Újtelep lelőhelyről. Arrabona 37, 1999, 65-82.
Manuscript accepted 24. 7. 2020

Translated by Borbála Nyíri

Súhrn preložila Erika Makarová
Eszter Melis, MA

Institute of Archaeology, Research Centre

for the Humanities

Hungarian Academy of Sciences

Centre of Excellence

4 Tóth Kálmán Street

$\mathrm{H}$ - 1097 Budapest

melis.eszter@btk.mta.hu

\title{
Ukazovatele sociálnej štruktúry na pohrebisku kultúry Gáta-Wieselburg na lokalite Hegyeshalom, Mad’arsko
}

\author{
Eszter Melis
}

\section{SÚHRN}

V rokoch 1965 a 1966 boli na lokalite Hegyeshalom-Újlakótelep objavené kostrové hroby datované do prelomu staršej a strednej doby bronzovej podla mad’arskej chronológie (staršia doba bronzová podla stredoeurópskej chronológie; $2100-1600$ cal BC). Toto pohrebisko s 58 hrobmi predstavuje najväčšie pohrebisko kultúry Gáta-Wieselburg na území Mad’arska. Okrem vel'kého množstva recentných zásahov, minimálne 36 \% hrobov bolo zámerne opätovne otvorených niekedy $\mathrm{v}$ minulosti.

Ked’že l'udia sa „nepochovávajú sami“, výber predmetov, ktoré sprevádzali zomrelých, ako aj spôsob pochovania odráža úlohu jednotlivca v spoločnosti, alebo inak povedané sociálnu identitu človeka (Bösel 2008, obr. 3; Rebay-Salisbury 2012, 427, 428, 443, obr. 6; Rebay-Salisbury et al. 2018, 79). Na stanovenie "hodnoty“ jednotlivých hrobov v kontexte pohrebiska v Hegyeshalome ako celku bola použitá metóda tzv. kombinovaného výpočtu sociálneho indexu. Napriek vysokému počtu porušených hrobov boli na pohrebisku stále badatelné ukazovatele sociálnej nerovnosti: dva mimoriadne hroby žien, pohreby osôb s vysokým a osôb s najnižším sociálnym statusom, ktoré sa dali na základe štatistickej analýzy vlastností hrobových jám a hrobových príloh zretel'ne odlíšit od hrobov strednej vrstvy. Výskyt hrobov detí s vysokým sociálnym statusom nastoluje otázku inštitucionalizácie vertikálnej sociálnej hierarchie (Bösel 2008; Sosna 2009, 140-142). Otázka, akým spôsobom rekonštruovat’ v spoločnosti kultúry Gáta-Wieselburg komplexný proces, ktorý viedol k náčelníctvu, môže byt’ zodpovedaná len analýzou a komparáciou d’alších vel'koplošných pohrebísk a sídlisk na území západného Mad’arska, východného Rakúska a juhozápadného Slovenska. 